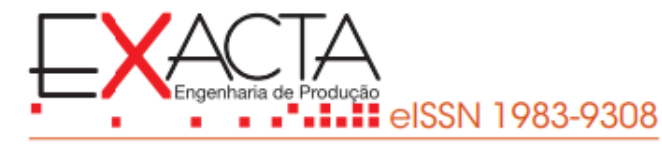

\title{
USING AHP TO IMPROVE MANUFACTURING PROCESSES IN TPM ON INDUSTRIAL AND PORT COMPLEX
}

\section{UTILIZANDO O AHP PARA MELHORIA DE PROCESSOS DE FABRICAÇ̃̃O EM TPM EM UM COMPLEXO INDUSTRIAL E PORTUÁRIO}

Recebido em: 27 fev. 2020

Aprovado em: 26 mar. 2020

Versão do autor aceita publicada online: 26 mar. 2020

Publicado online: 19 maio 2021

Como citar esse artigo - American Psychological Association (APA):

Sousa, J. V., Melo, F. J. C., Aquino, J. T., \& Jerônimo, T. de B. (2021, jul./set.). Using AHP to improve manufacturing processes in TPM on industrial and port complex. Exacta, 19(3), 523549. DOI: https://doi.org/10.5585/exactaep.2021.16693.

Submeta seu artigo para este periódico $\bigoplus$

Dados Crossmark 


\title{
USING AHP TO IMPROVE MANUFACTURING PROCESSES IN TPM ON INDUSTRIAL AND PORT COMPLEX
}

\author{
UTILIZANDO O AHP PARA MELHORIA DE PROCESSOS DE FABRICAÇÃO EM TPM EM UM \\ COMPLEXO INDUSTRIAL E PORTUÁRIO
}

\author{
iD Juliana Valença Sousa ${ }^{1}$ \\ iD Fagner José Coutinho de Melo² \\ iD Joás Tomaz de Aquino 3 \\ iD Taciana de Barros Jerônimo ${ }^{4}$
}

\author{
${ }^{1}$ Mestre em Engenharia de Produção \\ Universidade Federal de Pernambuco - UFPE \\ Recife, Pernambuco, Brasil. \\ juliana_valenca2@me.com \\ ${ }^{2}$ Doutor em Engenharia de Produção \\ Universidade Federal de Pernambuco - UFPE \\ Recife, Pernambuco, Brasil. \\ fagnercoutinhomelo@gmail.com \\ ${ }^{3}$ Mestre em Administração \\ Universidade Federal de Pernambuco - UFPE \\ Recife, Pernambuco, Brasil \\ joastomaz@outlook.com \\ ${ }^{4}$ Doutora em Engenharia de Produção \\ Universidade Federal de Pernambuco - UFPE \\ Recife, Pernambuco, Brasil. \\ taciana.barros@gmail.com
}

Recebido em: 27 fev. 2020

Aprovado em: 26 mar. 2020
Abstract: This paper aimed to develop a model to rank the critical factors for the improvement of the production process from the point of view of Total Productive Maintenance (TPM) in six companies located in the Suape Industrial Complex region. The work was classified as applied research, qualitative and quantitative, exploratory and descriptive, and study of case. The proposed model developed used the Analytic Hierarchy Process (AHP) method using six criteria: Equipment Breakdown, Long Setup, Small Stops, Reduction in Speed, Defective Production, Start-up. The results showed that all the six criteria were considered as critical increment factors for improvement from the TPM and the decision-maker, and the factors that contributed the most were long setup and breakdown of equipment with almost $50 \%$. The study's contribution is developing a model that allows the possibility of a classificatory grouping of critical factors to increase improvement, from the point of view of the TPM and the decision-maker.

Keywords: TPM. AHP. Process improvements. Ranking. Suape.

Resumo: Este trabalho teve como objetivo desenvolver um modelo que classifique os fatores críticos para a melhoria do processo produtivo sob a ótica da Manutenção Produtiva Total (TPM) em seis empresas localizadas na região do Complexo Industrial de Suape. O trabalho classificou-se em pesquisa aplicada, qualitativa e quantitativa, exploratória e descritiva, e estudo de caso. O modelo proposto desenvolvido utilizou o método Analytic Hierarchy Process (AHP) utilizando seis critérios: Breakdown do equipamento, Long Setup, Small Stops, Redução da velocidade, Produção defeituosa, Start-up. Os resultados mostraram que todos os seis critérios foram considerados como fatores críticos de incremento para melhoria do TPM e do tomador de decisão, e os fatores que mais contribuíram foram longos setups e quebra de equipamentos com quase $50 \%$. A contribuição do estudo é desenvolver um modelo que permita a possibilidade de um agrupamento classificatório de fatores críticos para aumentar a melhoria, do ponto de vista do TPM e do tomador de decisão.

Palavras-chave: TPM. AHP. Melhorias de processo. Ranking. Suape. 


\section{Introduction}

The globalization of the economy has boundaries on negotiations, customers, and suppliers. Barrier-free trade provides gains on various levels of productive chains that are directly dealing with: employees, government through taxes, and the creation of organizations/enterprises world-class (Singh et al., 2012; Stefano and Kojikovski, 2015).

However, there are many difficulties in developing countries, for instance, in Brazil: the competition of transactional companies, bureaucracy and high government taxes, local labor without qualification, raw material and low-quality inputs, logistics bottlenecks (Guarda and Felipe, 2015).

On this, Pernambuco (a state located in the Brazilian Northeast), implemented and developed the industrial and port complex, called Suape. Suape was created in 1983, but only increased in 2007, it has about 100 companies in various branches: industry, logistics, service, and port; with different sizes (small, medium, big and world-class level); and multiple headquarters countries: England, the United States of America and Austria (Suape, 2017). It draws attention to private investors who intend to settle, and who seek to merge local labor with their employees (Moraes and Clemente, 2015).

In this context, we may notice the importance of how to deal with the Suape system of production and maintenance of their machines and equipment (Netland and Sanchez, 2014). So, the importance of maintenance strategy lies in the company's objectives: In essence low cost, differentiation on its product/service and the return of investment (Jasiulewicz-Kaczmarek and Saniuk, 2017), reducing the number of failures and resources used, focusing on efficiency (Labib et al., 1998), employees can feel motivated in a healthy environment (Singh and Kumar, 2017) focused on the Total Productive Maintenance (TPM) performance, since this is linked to continuous improvement (Sharma and Kodali, 2008). These objectives should be applied in the world-class quality products/services (Sivaram et al., 2014) to achieve organizational goals about how to lead whit critical resources (Ahuja and Singh, 2013).

Consequently, to conduct the organization to these goals is necessary to develop a way to analyze the best alternative of maintenance among the others; to analyze what is the best decision that maximizes profits and the use of resources and minimizes costs of TPM.

According to this scenario presented, it was conducted a case of study using the hierarchy of critical factors on the productive process's improvements. A hierarchy is an efficient way to organize complex decisions. It is efficient in two ways: first- structurally, for representing a Suape Total Productive Maintenance system; second -functionally, for controlling and passing information to the operational labor levels. To select the best alternative, between different outsourcing contracts, in terms of maintenance services, this was used the Analytic Hierarchy Process (AHP) method. 
The AHP captures priorities from paired comparison judgments of decision elements. It also allows the measurement of tangible and intangible criteria. It decomposes decision into a hierarchy, and each one can be analyzed independently in the pairwise comparation. When we are making the comparisons, the decision-makers can use real data about the TPM in business performance. The AHP uses the human judgments, performing the evaluations of critical factors in maintenance process (Raouf and Ben-Daya, 1995; Labib et al., 1998; Kodali and Chandra, 2001; Bertolini et al., 2004; HajShirmohammadi and Wedley, 2004; Garg and Deshmukh, 2006; Ahuja and Khamba, 2008b; Kodali et al., 2009; Sharma et al., 2011; Singh et al., 2012; Ahuja and Singh, 2012; Jain et al.,2014; Emrouznejad and Marra, 2017). Although the AHP method is considered the most used method in the world, no work was found to develop a model to classify the critical factors for the improvement of the production process in the analysis of TPM in the industrial and port complex.

Thus, this paper aims to develop a model to rank the critical factors for the improvement of the production process on TPM analyses. It was conducting a survey in six companies located in the Suape Industrial Complex region, Northeast Brazil. The importance of research lay on the fact the suggested model seeks to help managers established the critical factors process of the productive process from the point of view of the TPM, classifying and categorizing them through a ranking determined by perception and choice of the decision-makers. Thus, they can prioritize the factors that have an improvement in the productive process.

The results of this research may have several relevant implications for the practice of engineering management and the decision-making process. Among them, it was possible to identify, classify, and rank the critical factor's increment of the improvement of the productive process, from the TPM and the decision-maker. This article is structured in six sections. This introduction discussed the importance, relevance, and objectives of the research. The second section contains a literature review with an emphasis on the basic concepts of this research. The third section presents the research methodology. The fourth section summarizes the results. In the fifth section, discussions of the results were presented. Finally, the last section gives the general conclusions of the research.

\section{Literature review}

The proposed model is primarily based on two methodologies: the first is the Total Productive Maintenance (TPM), and the second is the Analytic Hierarchy Process (AHP). Both methodologies will be discussed in this section. 
2.1 TPM

Total Productive Maintenance (TPM) is a program and also classified as a world-class manufacturing strategy (Ahuja and Khamba, 2008a; Breja et al., 2011) that focuses on preventive maintenance. TPM is also considered and categorized as Continuous Improvement Initiatives (CI) because it is related to quality management programs and quality certifications (Upadhyaya and Bhat, 2016).

Managers usually train and enable internal employees to repair and maintained their machines and equipment; to do this philosophy is important to convince them about the importance of the Total Quality Management (TQM) program within the production line. Those employees usually feel like real ownership (Ahuja and Khamba, 2008a), they had a responsibility to control and to adapt the maintenance of the machines to function correctly, through simple and routine maintenance, minor repairs, lubrication and cleaning, and other decisions. In these cases, maintenance specialists will deal with processes that require a higher level of complexity (Slack et al., 2007; Jha and Singh, 2016; DíazReza et al., 2019).

In this sense, the goal of TPM is to eliminate the variation that exists in production processes that caused: the stoppage, the defect, the unplanned break, according to Stevenson (2014).

TPM seeks to reach the limit of zero defects and accidents and to take advantage of the "hidden capacity" of equipment considered unreliable and ineffective (Ahuja and Khamba, 2008a) by eliminating the 6 large losses in the machines. These losses are directly linked to the Specific Improvement Pillar, or Overall Equipment Effectiveness (OEE) (Garg and Deshmukh, 2006), or Global Operating Efficiency, which consists of reducing possible problems in the system. The aim is to recognize the errors and to avoid them (Hansen, 2005)

Nakajima (1988), Takahashi and Osada (1990), Raouf and Ben-Daya (1995), Van der Wal and Lynn (2002), Garg and Deshmukh (2006) and Sousa (2017) enumerate and explain 6 major sources of losses: Equipment breakdown, Long setup, Small stops, Reduction in the speed of work, Defective production and rework and Start-up.

According to this view, we will show TQM examples. Singh and Ahuja (2015) developed research to evaluate the contributions of TPM to improve performance in the manufacturing industry in India. The authors concluded that proactive TPM initiatives could improve synergy between the maintenance department and the rest of manufacturing functions, bringing benefits such as defect elimination, increased process reliability, and cost savings.

Küçük \& Korkut (2016) investigated the general conditions of the TPM facilities in 77 product manufacturers in Turkey. The study showed that $75.3 \%$ of the companies studied had a maintenance department, even though it is not present in the organization chart, and $53.2 \%$ of the maintenance 
departments were quite developed. Among organizations studied, approximately $90 \%$ do not have TPM in place, and only $10 \%$ of companies use TPM. Of companies that do not have TPM, $19.5 \%$ consider implementing TPM in the future, while $22.1 \%$ do not have knowledge of TPM.

Jain et al. (2018) identify the main facilitator for TPM implementation in small and medium enterprises in India using graph theory. From the literature review, the authors identified 27 facilitators that were categorized into 6 groups: top management leadership, motivation, full employee involvement, interdepartmental coordination, and employee empowerment play a significant role in TPM implementation. Work culture and environment can increase employees' willingness to participate in TPM implementation.

Sahoo (2019) developed a multisectoral analysis framework to comparatively evaluate the synergistic and independent effect of TPM, and TQM improvement approaches in $231 \mathrm{food}$, beverage, textile, electrical and electronic manufacturing organizations using t-test statistics. The author concludes that adopting the integrated TPM $\times$ TQM approach has real benefits for the food, beverage, and electronics industry.

Manihalla et al. (2019) conducted a survey to identify factors that affect the implementation of total productive maintenance in service industries. The authors developed a questionnaire with 15 questions for TPM implementation and applied it to 45 small and medium service companies. The study found that $38 \%$ of the companies studied already used the TPM, and $62 \%$ of the companies studied have not yet implemented the TPM.

The main factors that are also identified contributed to the non-implementation of TPM are: lack of knowledge of TPM, lack of support in TPM implementation, lack of financial support, belief that TPM implementation is expensive and useful only for large-scale industries, lack of skills, employee resilience, lack of reward and management systems and confusion in selecting a specific TPM pillar.

Pačaiová and Ižaríková (2019) develop an approach to implement TPM based on the PDCA cycle (PLAN - DO - CHECK - ACT) and assess the influence of the occupational health and safety pillar on the

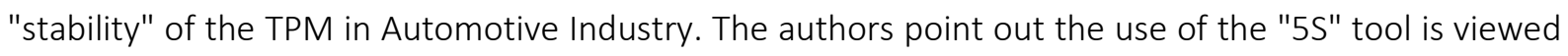
as a primary TPM tool.

Bataineh et al. (2019) developed a 13-step scheme to improve equipment production efficiency by facilitating the implementation of the fundamental principles of total productive maintenance in a beverage company. The proposed approach proved to be effective as it increased the overall efficiency of the equipment by $62.6 \%$ over a nine-month and other indirect improvements. 
The AHP (Analytic Hierarchy Process) is a methodology of decision making developed by Thomas L. Saaty - in the 1970s - to choose the best decision alternative considering the Pairwise Comparison Matrices (PCM). This methodology maximizes or minimizes an objective criterion through qualitative or quantitative values (Bertolini et al., 2004; Sharma et al., 2011). It is a method of decomposing a complex situation into parts. It is organizing these parts, or variables, into a hierarchical order (Labib et al., 1998). And it is one of the most used in the practice of the decisions to multiple criteria and decision-makers because it is simple and use a subjectivity analysis of the preference of view of the decision-maker (Wind and Saaty, 1980; Shafiee, 2015; Jerônimo et al., 2016; Sousa et al., 2017).

Saaty $(1977,1986,2008)$, Kodali and Chadra (2001) and HajShirmohammadi and Wedley (2004) explain that there are principles to be followed to solve the proposed decision problem:

a) Definition of the problem;

b) Decomposition of the structure of the problem into its essential elements, such as criteria, constraints, and alternatives. And their respective hierarchical levels, starting from the top (objective or more general focus) to the lower layer (Figure 1); where usually the alternatives listed, and one will be defined, according to the presented criteria;

Figure 1

Generic Hierarchical Structure In Decision Problems

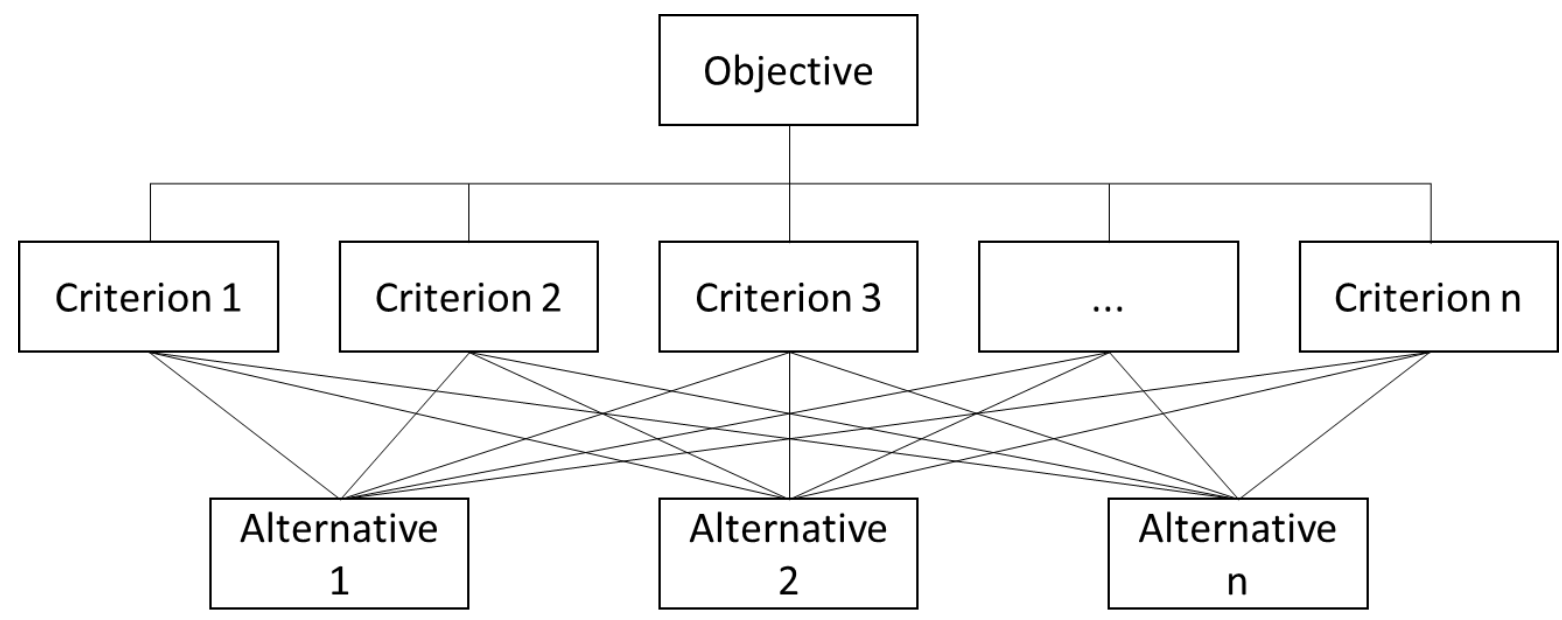

Source: Adapted from Saaty (1986).

c) Matching and comparing the importance's intensity of the relevant elements according to the decision-makers, understanding at each level of the hierarchy, according to the "The basic scale of absolute numbers" presented in Table 1. 
Table 1

The Basic Scale Of Absolute Numbers

\begin{tabular}{cl}
\hline Intensity & Definition \\
\hline 1 & Equal Importance \\
2 & Weak or slight \\
3 & Moderate importance \\
4 & Moderate plus \\
5 & Strong importance \\
6 & Strong plus \\
7 & Very strong or demonstrated importance \\
8 & Very, very strong \\
9 & Extreme importance \\
$1.1-1.9$ & If the activities are very close \\
\hline
\end{tabular}

Source: Adapted from Saaty (2008).

d) Synthesis of the priorities obtained through the Pairwise Comparison Matrices (PCM), from level 1 and their subsequent levels immediately, according to Table 2.

Table 2

(Reciprocal) Comparison Matrix of the AHP Method

\begin{tabular}{|c|c|c|c|c|}
\hline $\mathrm{Pk}$ & $\mathrm{C} 1$ & $\mathrm{C} 2$ & $\ldots$ & $\mathrm{Cn}$ \\
\hline $\mathrm{C} 1$ & $\mathrm{C} 1 / \mathrm{C} 1=1$ & $\mathrm{C} 1 / \mathrm{C} 2$ & $\ldots$ & $\mathrm{C} 1 / \mathrm{Cn}$ \\
\hline $\mathrm{C} 2$ & $\mathrm{C} 2 / \mathrm{C} 1=1 / \mathrm{C} 12$ & $\mathrm{C} 2 / \mathrm{C} 2=1$ & $\ldots$ & $\mathrm{C} 2 / \mathrm{Cn}$ \\
\hline$\ldots$ & $\ldots$ & $\ldots$ & 1 & $\ldots$ \\
\hline $\mathrm{Cn}$ & $\mathrm{Cn} / \mathrm{C} 1=1 / \mathrm{C} 1 \mathrm{n}$ & $\mathrm{Cn} / \mathrm{C} 2=1 / \mathrm{C} 2 \mathrm{n}$ & $\ldots$ & 1 \\
\hline
\end{tabular}

Source: Adapted from Saaty (1977).

The objective is to determine the relative weights of each criterion (up to the lowest levels) calculated using the eigenvector. After that, we normalized the eigenvector $(W)$; this gives us the order of priority of the criteria. Subsequently, the maximum eigenvalue ( $(\mathrm{max})$ is calculated, by multiplying the sum of the criterion judgment matrix with the column of the normalized eigenvector $(\Sigma=C i j x W i)$, with its result obtained if the measure of consistency and relative priority of the judgment.

It is necessary to analyze the It is necessary to analyze the decision-maker's judgments are coherent or not. We calculate it with the Coherence Index $(C l)$, this formula is: $\mathrm{Cl}=(\Lambda \max -n) /(n-1)$ and the Coherence Ratio $(C R)$ through the $C R=C l / R /$ solution.

After that, we calculate the Random Index (RI) or Consistency Index - designed for square matrices of order $\mathrm{n}$ with nonnegative elements. It is a randomly generated factor (Table 3 ) the number of decision criteria provided in the problem is the number of elements in the $R /$. 
Table 3

The Random Index (RI) or Consistency Index

\begin{tabular}{cccccccccccc}
\hline $\boldsymbol{n}$ & $\mathbf{1}$ & $\mathbf{2}$ & $\mathbf{3}$ & $\mathbf{4}$ & $\mathbf{5}$ & $\mathbf{6}$ & $\mathbf{7}$ & $\mathbf{8}$ & $\mathbf{9}$ & $\mathbf{1 0}$ & $\mathbf{1 1}$ \\
\hline RI & 0.00 & 0.00 & 0.58 & 0.90 & 1.12 & 1.24 & 1.32 & 1.41 & 1.45 & 1.49 & 1.51 \\
\hline
\end{tabular}

Source: Saaty (1977).

Regarding this, Saaty $(1977,2008)$ affirms that if the value of $C R<10 \%$ or 0,10 , the judgments are consistent, that is, one can proceed with the calculations of the method. On the other hand, if the $C R \geq 0.10$ the judgments, that means the original parity comparison matrix should be re-evaluated because it had inconsistency.

e) The choice of alternative, the final values of each alternative is obtained after performing the calculations described in the previous steps $(V, W, \max , I C, R I, C R)$ in each sub-criterion and criterion. Then, the alternatives are judged by each criterion, a decision matrix is built for classification and prioritization composed of the alternatives, and finally chooses the alternative that has the highest value in the recommended priority order.

The AHP is a single criterion synthesis method applicable to situations involving subjective judgments and can evaluate qualitative and quantitative factors, whether tangible or intangible criteria. It provides preference consistency measures and is widely used because its use is appropriate for both individual decision-making and decision-making groups (Almeida et al., 2015). The AHP method has several positive aspects:

- Ability to deal with problems involving both quantitative and qualitative variables;

- It can provide numerical weights for subjective judgments of quantitative or qualitative alternatives;

- It is easy to use, understand and develop by the decision-maker;

- How variables are aggregated requires the decision-maker to participate in the problem structuring and assessment process actively;

- Minor changes in the hierarchy stabilized by the decision-maker;

- Decision-makers can sort and compare a smaller list of items, making it easier to see their preferences;

- Synthesizes the results in an ordered list that can allow comparing the relative importance of each factor. 
The use of the additive model presents the need for its variables to be independent so that the behavior of one of them is random. This need lies in the fit of the model that can impact the estimation of the parameters (Almeida et al., 2015; Jerônimo et al., 2016). In this sense, residual factors and possible measurement errors will be estimated and tolerated by the use of the AHP method. Thus, any independent variable will not be correlated with a set of other independent variables, and one will be prioritized over the others, since there is no collinearity, and the variables are not autocorrelated. They are not collinear, a strong correlation between two (or more) independent variables cannot be indicated. In this research, the AHP method was used since the criteria considered in the decision problem are independent of each other, and it was identified that the performance compensation between criteria (Almeida et al., 2015). The decision-makers presented compensatory rationality, that it means, an excellent evaluation in another criterion can compensate for an alternative with bad evaluation in one criterion.

Other compensatory methods, such as Analytic Network Process (ANP), a specific case of the AHP, have not been considered by this research. Because it considers that there is a dependence between criteria and alternatives between their levels and with other levels (Sharma et al., 2019), other compensatory methods like Macbeth, Smarts/Smarter, the veto additive, and Fitradeoff were not used due to the own problem of this research.

Although the AHP is the most used method in the world (Almeida et al., 2015), few studies integrate AHP and TQM. In a search conducted on the Web of Science database using the keywords AHP + TQM and TQM + AHP, we found only 7 published research related to the theme that is highlighted.

Madu (1994) proposed to study how TPM could be applied to improve the effectiveness of a maintenance fluctuation system using the AHP method. The author concludes that minor changes to the operating environment can minimize the cost of a maintenance operation based on the TPM approach. Labib et al. (1997) proposed an approach to TPM implementation to achieve World Class Manufacturing (WCM) status using AHP and the Fuzzy Logic Controller applied in the UK. The authors conclude that the approach contributes to the development of a strategic World Class Manufacturing (WCM) program.

Kodali and Chandra (2001) developed a multicriteria decision model using AHP to justify the implementation of TPM in Indian industries. The developed model showed that the implementation of TPM could bring reforms and improvements in terms of equipment effectiveness, better product quality, promised delivery dates, and favorable workplace.

Huang et al. (2009) proposed an effective and convenient performance evaluation model for the implementation of Statistical Process Control based on Six Sigma the 'Define-measure-analyzeimprove-control' (DMAIC) methodology using AHP in a Taiwanese LCD industry. The developed model emerged from five strategies to improve performance: management support in Statistical Process 
Control (CEP) implementation, financial support, staff training, CEP team building, and reduction in control variations for normal distribution.

Sadeghi and Manesh (2012) developed a study to evaluate different maintenance strategies for transformer equipment from Esfhan's Mobarakeh Steel Company and select the best strategy. The authors concluded that the best maintenance strategy for transformer equipment is World Class Maintenance Systems.

Piechnicki et al. (2015) used the AHP method to prioritize critical success factors that influence TPM implementation during each phase of the production process in six Brazilian companies. The authors conclude that while some important essential factors of success are highlighted in the literature, these factors have different importance at each stage of TPM implementation.

Shinde and Prasad (2018) used AHP to classify the eight TPM pillars according to their importance in relation to four parameters: Productivity, Cost, Quality, and Time Delivery in automotive industries in India. Autonomous maintenance (JISHU HOZEN) and focused improvement (KOBESTU KAIZEN) are considered the most important pillars. Autonomous maintenance focuses on Quality Improvement, which increases productivity, meanwhile focused improvement has a high impact on productivity, reducing multiple losses, increasing production rate, keeping the delivery schedule fast, and reducing manufacturing cost.

With the description of the above studies, it was evident that no studies were found in the literature that relates the critical factors for improving the production process from the point of view of TPM with AHP in an Industrial and Port Complex.

\section{Methodology}

This research can be classified as applied according to its objective, which is the production of knowledge to be used in a practical way and focused on solving problems (Cooper and Schindler, 2013). Regarding the approach, this research was classified as qualitative and quantitative. The qualitative dimension aimed to study a specific phenomenon in-depth, in order to obtain a valid interpretation that is "why" and "how" happens, focusing on the processes of the object of study (Hair and Page, 2018). The quantitative dimension sought to convert the opinions of the six decision-makers of the companies studied into numerical data to modulate the situation, on industrial and port complex, in a proposed model for the classification of critical factors for the improvement of the production process in the analysis of TPM and uses the preferences for the elaboration of the multicriteria analysis using the AHP method. 
The AHP is an additive mathematical method of decision support that can deal with can deal with qualitative and quantitative aspects, whether tangible or intangible, and can also consider the differences and conflicts of the opinion of decision-makers (SAATY, 1990). The use of the AHP method was appropriate since the criteria considered in the decision problem are independent of each other. Besides this, the decision-maker rationality was identified as compensatory due to the decision problem, itself.

Regarding the objective, this research was classified as exploratory and descriptive. Exploratory research is characterized by providing a rough view of a problem to make it explicit or building hypotheses. This type of research is generally used as the first step of a broader investigation (Hair and Page, 2018). And descriptive research aims to describe the characteristics of a given phenomenon without manipulating it.

The method of this research can be classified as a study of case since the developed model was applied in a group formed by six different manufacturing companies located in the Suape Industrial Complex (Pernambuco / Brazil). Those companies were selected considering three parameters: (i) it is located in Suape industrial zone; (ii) have the manufacturing industry as its business sector and (iii) use the TPM. A questionnaire was developed to measure the critical improvement factors, from the perspective of the TPM in the Suape Industrial Complex. This questionnaire was sent by email to the managers of the organizations studied and is shown in Table 4.

\section{Table 4}

Preliminary Questionnaire

\begin{tabular}{|c|c|}
\hline Question Code & Questions \\
\hline P1 & Did you notice the reduction in batch size? \\
\hline $\mathrm{P} 2$ & Have you noticed the reduction in waiting time for materials, information, and people? \\
\hline P3 & Has the decrease in excessive or improper transport of products been perceived? \\
\hline P4 & Are maintenance plans focused on critical equipment? \\
\hline P5 & Is there a preference for preventive maintenance rather than corrective maintenance? \\
\hline P6 & There was a reduction of the equipment failures in the production line \\
\hline P7 & Do operators feel empowered to perform standalone maintenance on their machines? \\
\hline P8 & $\begin{array}{l}\text { Do operators know the basic operations of their equipment and are involved in the } \\
\text { investigation of anomalies? }\end{array}$ \\
\hline P9 & $\begin{array}{l}\text { Have you noticed the reduction of defective products and reworked in the manufacturing } \\
\text { processes? }\end{array}$ \\
\hline P10 & Are the cycle times known to the equipment operators? \\
\hline P11 & Has it started delivering the orders within the deadlines set by the customer? \\
\hline
\end{tabular}

Source: The authors (2021). 
The Aggregation Individual Judgments (AIJ) metrics were used to aggregate the values of the responses of the 6 subjects of the research, that is, to gather the individual judgments that have the advantages of being flexible, realistic and practical because they do not require the intermediary of a moderator within the group, and the construction of the consensus derives from the decision of the final judgment of the group of respondents through the matrix decision tool, this convergence is fundamental for groups of heterogeneous composition (Forman and Peniwati, 1998; Escobar and Moreno-Jiménez, 2007; Sousa et al., 2017; Emrouznejad and Marra, 2017). The steps to be taken to compose the analysis and hierarchy of critical improvement factors, focusing on the TPM are shown in Figure 2.

a) Identify and classify the critical improvement factors, from the point of view the Pillar of the TPM (Pillar Specific Improvements);

b) Apply the questionnaire to collect data answers;

c) Relate the two variables (improvement and non-improvement from the TPM perspective) to the critical factors;

d) We use AHP to hierarchically order the managerial importance of improvements and nonimprovements from the viewpoint of TPM;

e) Analyze the factors of this AHP rank of improvements and non-improvements.

\section{Results}

This section presents the results of this survey conducted at six companies in the food, aluminum manufacturing, air conditioning, ceramics, wind power, and refrigerant companies, all located in the Suape industrial complex. The proposed hierarchical structure model for critical improvement factors is presented in Figure 2. 
Figure 2

Proposed Model Of The Hierarchical Structure of Critical Improvement Factors From The TPM Perspective

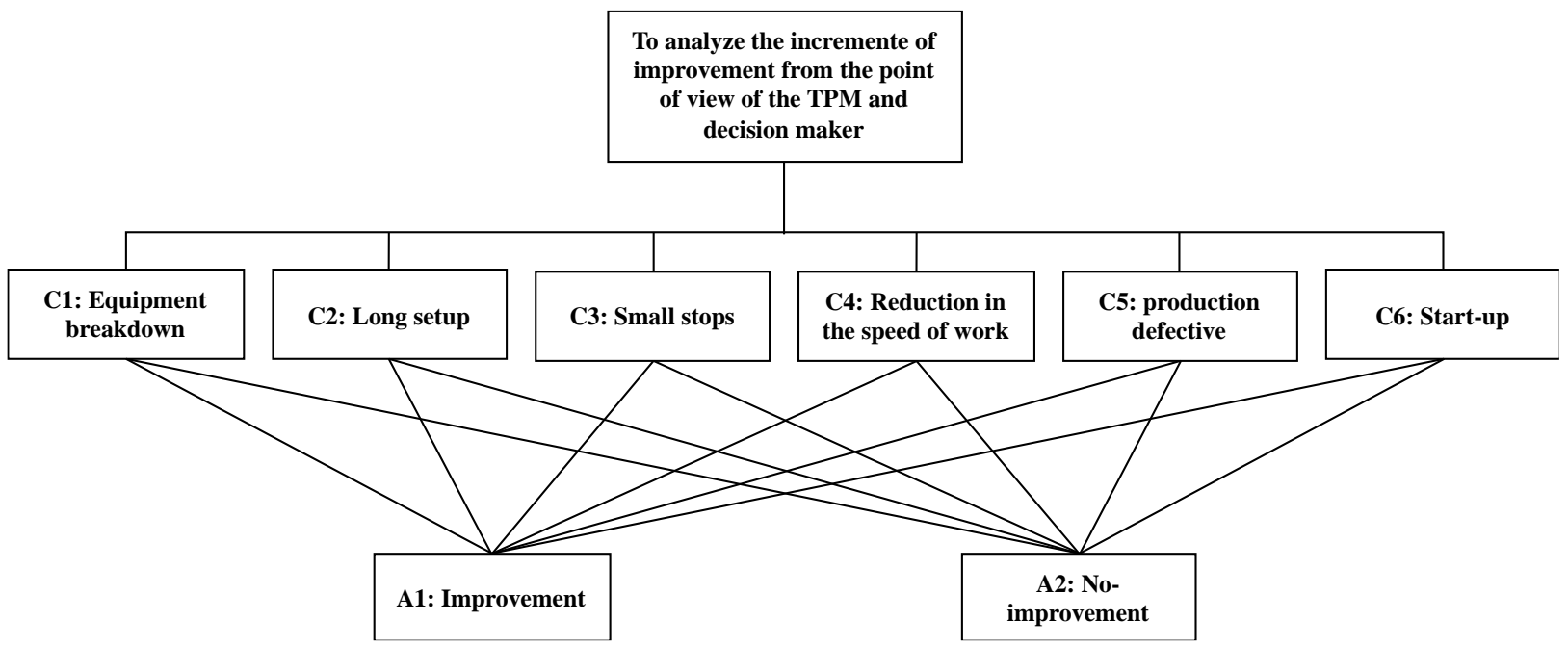

Source: The authors (2021).

The judgments and hierarchy of the critical factors were given by six decision-makers of the companies studied. The decision-makers in question are production managers who have over 10 years of experience in the industrial sector. Despite the problems generated by corruption investigated by Lava Jato, Suape, although less rapidly, and yet it is considered a vital investment center by both the state and private companies (Moraes and Clemente, 2015; Sousa, 2017).

Therefore, it is necessary to understand what are specific improvements and their elements and can positively affect the level of productivity and quality of organizations in general, having as a starting point the operation, i.e., the efficiency and performance of machines and equipment used in production lines, excess inventory and materials used in the manufacture of products (Ahuja and Singh, 2017).

\subsection{The companies studied}

The proposed model was applied to six companies selected according to three parameters: (i) be located in Suape industrial zone; (ii) have the manufacturing industry as its business sector and (iii) use the TPM. Decision-makers were consulted to identify critical factors for improving the production process from a TPM standpoint using the AHP method procedures.

The companies studied are located in the Suape Industrial Complex region, Northeast of Brazil, it is essential to point out that in agreement with the survey respondents, it was decided to keep the 
companies' name/brand confidential. Referring to them only by industry. Still, it was possible to make a brief analysis of these companies:

- Company 1- Located at Polo Food \& Beverage, which houses important companies in the sector, it has been operating in the country for about 90 years. It has operations in 190 countries and 15 factories in Brazil in several cities in the states of São Paulo, Minas Gerais, Goiana, and Pernambuco. In Suape, company 1 is considered as a strategic hub, hence its choice to settle since 2005, the factory produces food portfolio items, personal care, cleaning items, and ice cream. It currently employs about 2,000 employees.

- Company 2 - Company that produces aluminum and rigid plastic packaging for use with snacks, confectionery, cheese, yogurt, fresh produce, and beverages. In operations since 1860, with its first headquarters in Australia, the group is currently present in 43 countries, with the collaboration of about 50 thousand employees and a structure of more than 250 units.

- Company 3 - A company that produces air ducts and cable changers, considered the only manufacturer of this type of conductors in Northeastern of Brazil, has supplied its ducts to the Vard Promar and Atlântico Sul shipyards and is accredited to provide services to Petrobras. This Company is located in the metalworking pole of the Suape Port Industrial Complex, with branches in the main capitals of the Northeast. It currently generates about 750 jobs and invested around approximately US\$2.5 million in its facilities inaugurated at the end of December 2015.

- Company 4 - Company 4 is a brand founded in 1996, and opened in Suape in 2005, is owned by one of the largest plastic pipe manufacturing companies with revenues of US\$ 5.7 billion. Located in Mexico, manufactures PVC pipes for installations, plumbing, irrigation, building infrastructure and sanitary fittings. In Brazil, it has around 2,400 employees in seven different factories located in the states of Paraná, São Paulo, Minas Gerais, Goiás, and Pernambuco. Its administrative headquarters in Brazil is in São Paulo, the capital.

- Company 5 - Argentine subsidiary manufacturer opened in Suape in May 2008, manufactures direct and alternating current wind turbines. Considered one of Suape's anchor companies, with two industrial units and revered as a milestone in the history of the state of Pernambuco. It has seen the creation of a wind energy production pole, which encouraged the arrival of other companies linked to the wind turbine production chain. It invested around approximately US\$ 34.4 million in its facilities. Its production capacity is 200 wind power generation equipment per year and had 388 employees. 
- Company 6 - It is a Company with over 20 years in the market and manufacturer of soft drinks, teas, energy drinks, isotonic drinks, juices, dairy products, and mineral water. The factory installed in Suape along with three others located in the states of Pernambuco and Paraiba had an installed production of 550 million liters of beverages per year, and it generated 2,000 direct and 20,000 indirect jobs. It is currently part of a joint venture with two more subsidiaries, which together have 15,000 employees, revenues of approximately US\$1.5 billion, and a production capacity of 3 billion liters/year.

\subsection{Decomposition of the structure of the problem in its basic elements}

According to Almeida et al. (2015), the construction of the model and the choice of the decision support method are associated with the decision actors. After identifying the decision actors, it is necessary to identify the type of problem, the profile, and the cognitive process of the decision-makers, so that the appropriate multicriteria method is suggested. In this paper, the decision-makers are the six managers of the organizations studied.

Taking into consideration the purpose of this article: to develop a model to rank the critical factors for the improvement of the production process from the point of view of TPM in six companies located in the Suape Industrial Complex region, the stock space is formed by two alternatives called A1 = improvement, $\mathrm{A} 2$ = non-improvement.

Consequently, the multicriteria decision model is justified since there are two action alternatives (improvement or non-improvement) to choose from conflicting, independent, and exclusionary. For the established objective, six criteria were listed (Criteria: $\mathrm{C} 1$ = Equipment Breakdown, C2 = Long Setup, C3 = Small Stops, C4 = Reduction in Speed, C5 = Defective Production, C6 = Start-up). These criteria are used together because they are part of the TPM study. These are representing it in the quantitative process's modeling. In this study were not considered probabilistic criteria to establish the criteria. Table 5 presents the description of the six criteria of the proposed model. 
Table 5

Description of the Criteria

\begin{tabular}{|c|c|c|c|}
\hline Code & Criteria & Brief Description & References \\
\hline C1 & $\begin{array}{l}\text { Equipment } \\
\text { Breakdown }\end{array}$ & $\begin{array}{l}\text { Equipment malfunction can be considered as } \\
\text { malfunctioning equipment, that is, as the inability of a } \\
\text { good to achieve a certain level of performance. }\end{array}$ & \multirow{6}{*}{$\begin{array}{l}\text { Nakajima (1988), Takahashi and } \\
\text { Osada (1990), Raouf and Ben- } \\
\text { Daya (1995), Van der Wal and } \\
\text { Lynn (2002), Garg and Deshmukh } \\
\text { (2006), Ahuja (2015), Sousa } \\
\text { (2017), Jain et al. (2018) and } \\
\text { Manihalla et al. (2019) }\end{array}$} \\
\hline C2 & Long Setup & $\begin{array}{l}\text { The number of items that are no longer being produced } \\
\text { because the machine is being adjusted to produce a } \\
\text { new one. }\end{array}$ & \\
\hline C3 & Small Stops & $\begin{array}{l}\text { The number of items that stop being produced due to } \\
\text { process stops for minor adjustments. }\end{array}$ & \\
\hline C4 & $\begin{array}{l}\text { Reduction in } \\
\text { Speed }\end{array}$ & $\begin{array}{l}\text { This is the number of items that are no longer being } \\
\text { produced because the equipment is operating at a } \\
\text { slower than normal speed. This fact may be related to } \\
\text { the lack of preventive maintenance. }\end{array}$ & \\
\hline C5 & $\begin{array}{l}\text { Defective } \\
\text { Production }\end{array}$ & $\begin{array}{l}\text { It is the number of items lost when the process has } \\
\text { already started (when a problem occurs during the } \\
\text { operation, which will generate the loss of the product). }\end{array}$ & \\
\hline C6 & Start-up & $\begin{array}{l}\text { It is the number of items lost when the process has not } \\
\text { yet started (when problems with the inputs are } \\
\text { identified, which prevents their entry into the process } \\
\text { and generates their loss). }\end{array}$ & \\
\hline
\end{tabular}

Source: The authors (2021)

Subsequently, these criteria were contrasted and correlated with the priority/preference intensity level, as presented in Saaty's (2008) fundamental absolute number scale.

\subsection{Pairing, comparative judgment, and synthesis of priorities}

Aggregation Individual Judgments (AIJ) was used for comparison and aggregation. A matrix is constructed where all criteria must be matched, and decision-makers should judge those located to the left with those at the top, according to the level of importance or intensity they understand in accordance with Table 6.

After the judgment and the reciprocal comparisons, the relative weights/priorities of each criterion are calculated by means of the eigenvector $(V)$ - which is the geometric mean of all the presented criteria - and in the sequence, these values will be normalized ( $W$ ), that is, each criterion will be divided by the sum of the weights of all the criteria (Saaty, 1990). 
Table 6

Comparison Matrix for Classification of Critical Improvement Factors from the TPM Perspective

\begin{tabular}{|c|c|c|c|c|c|c|c|c|c|}
\hline & & $\mathrm{C} 1$ & $\mathrm{C} 2$ & C3 & C4 & C5 & C6 & $\begin{array}{l}\text { EIGENVECTOR } \\
\text { (V) }\end{array}$ & $\begin{array}{l}\text { NORMALIZED } \\
\text { EIGENVECTOR } \\
\text { (W) }\end{array}$ \\
\hline BREAK & $\mathrm{C} 1$ & 1 & 1 & 2 & 2 & 3 & 1 & 1,51 & 0,238 \\
\hline LONG SETUP & C2 & 1 & 1 & 4 & 1 & 1 & 4 & 1,59 & 0,25 \\
\hline SMALL STOPS & C3 & 0,5 & 0,25 & 1 & 1 & 2 & 1 & 0,79 & 0,125 \\
\hline REDUCT IN THE SPEED & C4 & 0,5 & 1 & 1 & 1 & 1 & 2 & 1 & 0,157 \\
\hline DEFECTIVE PROD & C5 & 0,33 & 1 & 0,5 & 1 & 1 & 2 & 0,83 & 0,131 \\
\hline START-UP & C6 & 1 & 0,25 & 1 & 0,5 & 0,5 & 1 & 0,63 & 0,099 \\
\hline SUM & $\Sigma$ & 4,33 & 4,5 & 9,5 & 6,5 & 8,5 & 11 & 6,36 & 1 \\
\hline
\end{tabular}

Source: The authors (2021).

Afterward, it should be analyzed whether the judgments are in fact coherent or consistent for validating the results, using the following indices and their respective values for this research: a) maximum eigenvalue ( $\Lambda \max =6.567) ; b)$ consistency index $(C l=0.113) ; c)$ consistency index, in the case as there were 6 criteria $(n=6)$, the value, according to Table 3, will be of $R I=1.24$; d) consistency ratio ( $C R=0.092$ or $9.92 \%$, i.e., $<10 \%$, which proves its consistency).

\subsection{Choice of alternative}

In this step, the decision matrix following the comparative judgment follows. At this time, both alternatives and a single decision criterion will be confronted until all the criteria are confronted by means of an array of order $n \times n$, where $n$ represents the number of alternatives. Six matrices will be judged $2 \times 2$ because there are six elements in level 2 and two alternatives of choice. The Table 7 presents the six matrices considered, which are the alternatives of this research, as shown in Figure 2. 
Table 7

Matrix of Judgment and Comparison of Alternatives and Criterion

\begin{tabular}{|c|c|c|c|c|c|c|c|c|c|}
\hline BREAK & 0.237 & & & & REDUCT IN THE SPEED & 0.157 & & & \\
\hline C1 & A1 & A2 & V & W & C4 & A1 & A2 & V & W \\
\hline A1 & 1.00 & 9.00 & 3.00 & 0.900 & A1 & 1.00 & 9.00 & 3.00 & 0.900 \\
\hline A2 & 0.11 & 1.00 & 0.33 & 0.100 & A2 & 0.11 & 1.00 & 0.33 & 0.100 \\
\hline SUM & 1.11 & 10.00 & 3.33 & 1.000 & SUM & 1.11 & 10.00 & 3.33 & 1.000 \\
\hline$\wedge \mathrm{MAX}=2.00$ & $\mathrm{Cl}=0.00$ & $\mathrm{RI}=0.00$ & $C R=0.00$ & & $\wedge \mathrm{MAX}=2.00$ & $\mathrm{Cl}=0.00$ & $\mathrm{RI}=0.00$ & $C R=0.00$ & \\
\hline LONG SETUP & 0.249 & & & & DEFECTIVE PROD & 0.140 & & & \\
\hline C2 & A1 & A2 & v & W & C5 & A1 & A2 & V & W \\
\hline $\mathrm{A} 1$ & 1.00 & 8.00 & 2.83 & 0.889 & A1 & 1.00 & 8.00 & 2.83 & 0.889 \\
\hline A2 & 0.13 & 1.00 & 0.35 & 0.111 & A2 & 0.13 & 1.00 & 0.35 & 0.111 \\
\hline SUM & 1.13 & 9.00 & 3.18 & 1.000 & SUM & 1.13 & 9.00 & 3.18 & 1.000 \\
\hline$\wedge \mathrm{MAX}=2.00$ & $\mathrm{Cl}=0.00$ & $R I=0.00$ & $C R=0.00$ & & $\wedge \mathrm{MAX}=2.00$ & $\mathrm{Cl}=0.00$ & $\mathrm{RI}=0.00$ & $C R=0.00$ & \\
\hline SMALL STOPS & 0.125 & & & & START-UP & 0.092 & & & \\
\hline C3 & A1 & A2 & V & W & C6 & A1 & A2 & V & W \\
\hline $\mathrm{A} 1$ & 1.00 & 8.00 & 2.83 & 0.899 & A1 & 1.00 & 4.50 & 2.12 & 0.818 \\
\hline A2 & 0.13 & 1.00 & 0.35 & 0.111 & A2 & 0.22 & 1.00 & 0.47 & 0.182 \\
\hline SUM & 1.13 & 9.00 & 3.18 & 1.000 & SUM & 1.22 & 5.50 & 2.59 & 1.000 \\
\hline$\wedge \mathrm{MAX}=2.00$ & $\mathrm{Cl}=0.00$ & $\mathrm{RI}=0.00$ & $C R=0.00$ & & $\wedge \mathrm{MAX}=2.00$ & $\mathrm{Cl}=0.00$ & $\mathrm{RI}=0.00$ & $C R=0.00$ & \\
\hline
\end{tabular}

After evaluation, judgment, placement of values, calculation of the eigenvector $(V)$ followed the normalization process $(W)$ then they were calculated: maximum eigenvalue ( $\Lambda$ max), consistency index $(C l)$, the randomness index $(R /)$, and the consistency ratio $(R C$ or $C R)$ of each of the six criteria.

Through the analysis of Table 7, it was possible to perceive, according to the decision-makers, that after the implementation of the TPM there was a significant improvement (A1) in all six judged elements, i.e. (C1) the perception of the reduction in the size of the lots, since they prioritized the preventive maintenance, mainly in equipment considered critical, as well as a decrease in equipment failures; (C2) in the improvement of setup time, because the operators can keep their machines running, because they are able to do autonomous maintenance and minor repairs; (C3) the change for the better in the case of small unnecessary stops due to excessive or inappropriate transportation, as well as the time spent by the employee waiting for materials, information and even people; (C4) the improvement of the employees' understanding of the cycle time of the machines and equipment they operate; (C5) this understanding linked to the knowledge of the basic operations of the equipment and investigation of the anomalies found increased the reduction of the defective products; (C6) the consequence of the improvements presented reflected in the delivery deadline of the orders established by the customer. 


\section{Table 8}

Decision Matrix for the Classification and Hierarchy of Improvements and non-Improvements

\begin{tabular}{|c|c|c|c|c|c|c|c|c|}
\hline & $\mathrm{C} 1$ & C2 & C3 & C4 & C5 & C6 & $\begin{array}{c}\text { EIGENVECTOR } \\
\text { (V) }\end{array}$ & $\begin{array}{l}\text { NORMALIZED } \\
\text { EIGENVECTOR } \\
\text { (W) }\end{array}$ \\
\hline C & 0,238 & 0,25 & 0,125 & 0,157 & 0,131 & 0,099 & & \\
\hline $\mathrm{A} 1$ & 0,9 & 0,89 & 0,89 & 0,9 & 0,89 & 0,82 & 0,89 & $88,63 \%$ \\
\hline $\mathrm{A} 2$ & 0,1 & 0,11 & 0,11 & 0,1 & 0,11 & 0,18 & 0,11 & $11,37 \%$ \\
\hline SOMA & 1 & 1 & 1 & 1 & 1 & 1 & 1 & \\
\hline
\end{tabular}

Source: The authors (2021).

And finally, in Table 8, all values obtained by the normalized vectors $(W)$ of Table 6 are grouped and leveled together with those of the judgment matrices (alternatives $x$ criterion) of Table 7. Besides, both vectors ( $\mathrm{A} 1$ and $\mathrm{A} 2$ ) were calculated and normalized, and through this process, the result of the decision vector is reached, according to Saaty's model (2008).

Through the numbers obtained through the judgments of the decision-makers to the questions contained in the questionnaire (Table 4) and the calculations used (Tables 6, 7 and 8), it was possible to determine that all 6 criteria, represented by Figure 2, were classified as factors critical of improvements from the point of view of the TPM and the decision-maker, that is to say, the alternative A1 is to the one that besides having all the criteria is also the one of higher relative weight significantly, whose decision vector presented was $W=88,63 \%$

In descending order, the percentages of importance (ranking) of the managerial and maintenance aspects are as follows: C2: long setup (25\%); C1: equipment breakdown (23.8\%); C4: reduction in speed (15.7\%); C5: defective production (13.1\%); C3: small stops (12.5\%); C6: start-up (9.9\%), which are also represented in Figure 3 of the classification and final hierarchization of the improvements and non-improvements of the companies interviewed.

Also in accordance with the numbers presented in Figure 3, the elements that obtained an increment of the improvement were identified, that is, that were benefited by the implantation and use of TPM, which were C2 and C1 (with almost $50 \%$ ), since there was a suppression of downtime and shortening of the tool change process, the configurations for the production of new products, etc., and if the employee knows the equipment he or she routinely handles, keeping the aspects such as cleaning machines and the environment and preventive adjustments, then the chances of failures and failures can decrease dramatically.

However, the $\mathrm{C} 6$ whose focus is the starting or start-up scheme or efficiency of the equipment, in other words, is the period between adjusting a new machine to go into operation or adjusting one new product to one that is already operating, it takes to reach its ideal, unchanged state for production. 
And this value resulting from the analysis and judgment was a 9.9\% improvement. This number further reflects the fact that not all deadlines set by customers are being duly complied with.

Through the results presented in this research through the classification and hierarchy of improvements from Total Productive Maintenance, it is possible to perceive the importance of this program in industries, in terms of quality, cost, productivity, morale, deadline, and customer and consumer satisfaction for the longevity of the company.

Figure 3

Final Hierarchy of Improvements and Non-Improvements In the Companies Interviewed

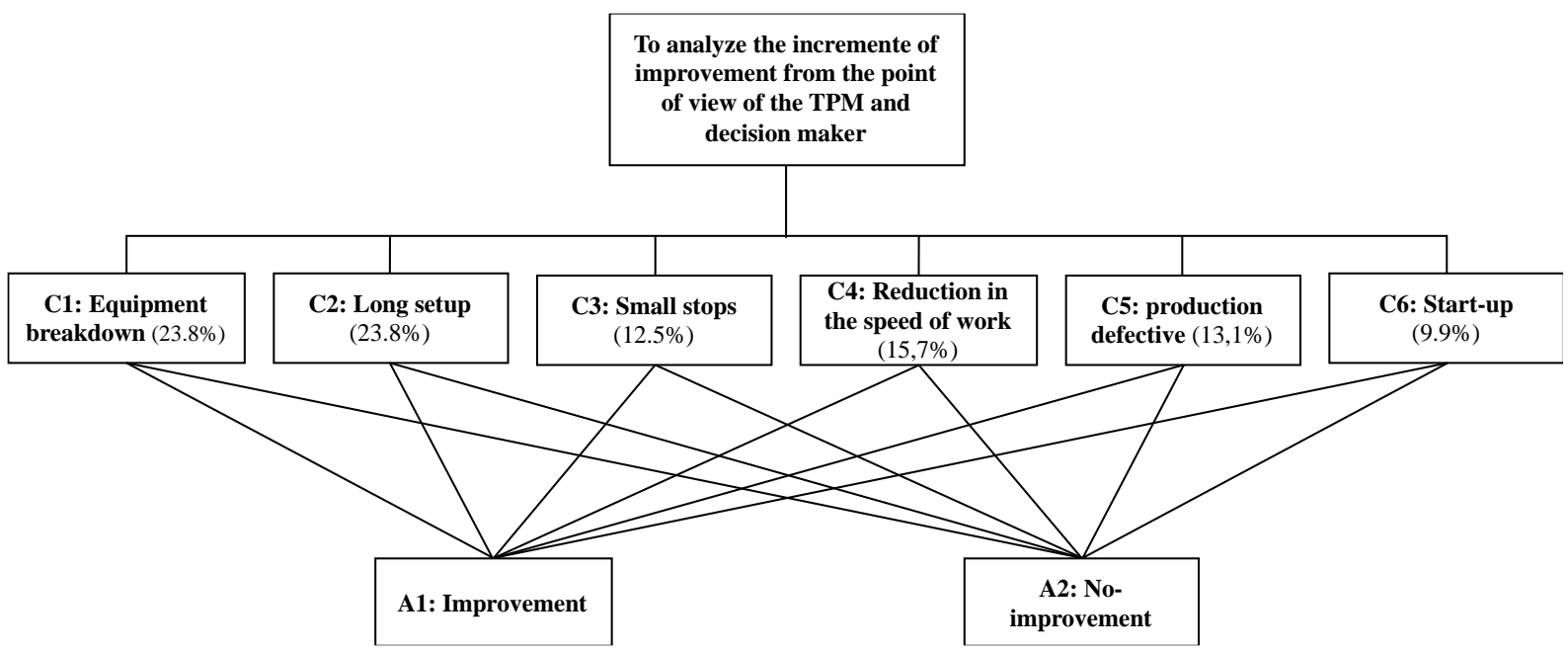

Source: The authors (2021).

\section{Discussion of the results}

This article has demonstrated the use of the AHP method to hierarchize the critical factors of improvements in the productive processes in the six companies surveyed and currently located in the region of the Suape Industrial Complex. Although this is exploratory research, the results of this paper have several practical implications that will guide senior management to appropriately direct resources at the right time to improve the organizational process. It contributed and helped the managers and decision-makers in the process of indicating these factors, classifying and categorizing through a ranking established by the perception and choice of the decision-makers themselves, who should be more attentive and prioritize their attention, especially to those who presented a low participation rate improvement.

Thus, the research's objective proposed was successful since it was possible to identify, classify, and hierarchize the critical factors for the improvement increment from the point of view of the TPM and the decision-maker. 
According to the results presented in Figure 3, all six expressed criteria were classified and categorized as A1: Critical Factor of Improvement (88.63\%). Among them, for analysis, the one that had the lowest percentage rate of contribution to the improvement was the C6 (start-up $=9.9 \%$ ). The hypothesis presented by the respondents is how leaders are training/reviewing their knowledge of machines and equipment newly acquired by companies, and the same analogy could be applied to the production of a new item that had never been previously requested.

The consequences described by the literature review presented, and in the process of gathering and collecting the data were the same. Thus, the critical factors contributing less to the improvement are directly related to the small delays due to unexpected stops ( $C 3=12.5 \%)$ and the non-conformity of the requested products ( $C 5=13.1 \%$ ), since the production lines are forced to work in low turnover ( $C 4=15.7 \%)$. However, as at the beginning of each operation, the employees act more cautiously, due to lack of knowledge of the operation of the system, the rate of machine downtime due to breakage is lower $(\mathrm{C} 1=23.8 \%)$. This precaution and reserve on the part of those who operate adjust the machines shorter, because they usually err less when they work with those machines ( $C 2=25 \%$ ).

\section{Conclusions}

This article aimed to develop a model to classify the critical factors for the improvement of the production process in the analysis of TPM in the Suape Industrial Complex, Northeast Brazil. The application of the proposed model sought to assist managers in prioritizing the critical factors of the production process from the point of view of TPM, classifying, and categorizing through a ranking established by the perception and choice of decision-makers.

It is believed that the work's results were a consequence of the characteristics of the sample and the perception of decision-makers. In this sense, the proposed approach is feasible to be implemented, since it guides managers and establishes itself in a logical sequence, providing decisionmakers and managers with a recommendation of which critical factors of the productive process from the point of view of TPM are the most in the organization.

The results of the proposed approach suggest several relevant implications for the practice of managers and the decision-making process in the Suape Industrial Complex. In the practical scenario, the study's contribution lies in the development of a model that allows the possibility of a classificatory grouping of critical factors to increase the improvement, from the point of view of the TPM and the decision-maker. Besides, the use of AHP allows the establishment of mathematical resolutions with qualitative standards, through the synthesis of results, which assist the decision-maker in the selection process, as this is a method of rational analysis of the appropriate response to the alternatives involved and according to the established criteria and parameters. 
In the academic scenario, this study becomes important, since no research was found in the literature that sought to develop a model to classify the critical factors for the improvement of the production process in the analysis of TPM in an Industrial Complex, bringing in the model an effective contribution to the thematic. As it is an exploratory study, it was not possible to make a comparison of the results found with results identified in the literature, due to the lack of articles discussing the theme.

For future work, it is recommended, a larger number of questions to be asked, a broader scope of companies to be researched by merging companies that have and do not have TPM implemented. Because what is wanted is a comparative analysis of earnings with different types of maintenance used and posterior the verification of the best method of maintenance management.

\section{Acknowledgments}

This study was financed in part by the Coordenação de Aperfeiçoamento de Pessoal de Nível Superior Brasil (CAPES) - Finance Code 001, the Conselho Nacional de Desenvolvimento Científico e Tecnológico - Brasil (CNPQ) and the Fundação de Amparo a Ciência e Tecnologia de PE.

\section{References}

1) Ahuja, I.P.S., \& Khamba, J.S. (2008a). An evaluation of TPM initiatives in Indian industry for enhanced manufacturing performance. International Journal of Quality \& Reliability Management, 25(2), 147-172. DOI: https://doi.org/10.1108/02656710810846925

2) Ahuja, I.P.S., \& Khamba, J. S. (2008b). Assessment of contributions of successful TPM initiatives towards competitive manufacturing. Journal of Quality in Maintenance Engineering, 14(4), 356-374. DOI: https://doi.org/10.1108/13552510810909966

3) Ahuja, I.P.S., \& Singh, P. (2012). Application of analytical hierarchy process for justification of TPM implementation in manufacturing organizations. International Journal of Technology, Policy and Management, 12(1), 37-47. DOI: https://doi.org/10.1504/IJTPM.2012.044967

4) Ahuja, I.P.S., \& Singh, P. (2017), Total Productive Maintenance - A Tool for World Class Manufacturing, International Journal of Advanced Production and Industrial Engineering. Special Issue on Operations \& Supply Chain Management, pp. 20-23.

5) Ahuja, I.S., \& Singh, P. (2013). Total productive maintenance: a tool for envisaging manufacturing competence. International Journal of Technology, Policy and Management, 13(2), 107-120. DOI: https://doi.org/10.1504/IJTPM.2013.053083

6) Almeida, A. T.; Cavalcante, C. A. V.; Alencar, M. H.; Ferreira, R. J. P.; De Almeida-Filho, A. T.; \& Garcez, T. V. (2015). Multicriteria and multiobjective models for risk, reliability and maintenance decision analysis. New York: Springer. DOI: https://doi.org/10.1007/978-3-319$\underline{17969-8}$ 
7) Bataineh, O., Al-Hawari, T., Alshraideh, H., \& Dalalah, D. (2019). A sequential TPM-based scheme for improving production effectiveness presented with a case study. Journal of Quality in Maintenance Engineering, 25(1), 144-161. DOI: https://doi.org/10.1108/JQME-07-2017-0045

8) Bertolini, M., Bevilacqua, M., Braglia, M., \& Frosolini, M. (2004). An analytical method for maintenance outsourcing service selection. International Journal of Quality \& Reliability Management, 21(7), 772-788. DOI: https://doi.org/10.1108/02656710410549118

9) Breja, S.K., Banwet, D.K. \& Iyer, K.C. (2011). Quality strategy for transformation: a case study. The TQM Journal, 23(1), 5-20. DOI: https://doi.org/10.1108/17542731111097452

10) Cooper, D. R. \& Schindler, P. M. (2013), Business Research Methods, 12th Edition. McGraw-Hill Education.

11) Díaz-Reza, J.R., García-Alcaraz, J.L. \& Martínez-Loya, V. (2019). TPM Literature Review”, in DíazReza, J. R., García-Alcaraz, J.L. and Martínez-Loya, V, Impact Analysis of Total Productive Maintenance Critical Success Factors and Benefits, Springer Nature, Switzerland, pp.23-29

12) Emrouznejad, A., \& Marra, M. (2017). The state of the art development of AHP (1979-2017): A literature review with a social network analysis. International Journal of Production Research, 55(22), 6653-6675. DOI: https://doi.org/10.1080/00207543.2017.1334976

13) Escobar, M.T., \& Moreno-Jimenéz, J.M. (2007). Aggregation of individual preference structures in AHP-group decision making. Group Decision and Negotiation, 16(4), 287-301. DOI: https://doi.org/10.1007/s10726-006-9050-x

14) Forman, E., \& Peniwati, K. (1998). Aggregating individual judgments and priorities with the analytic hierarchy process. European journal of operational research, 108(1), 165-169. DOI: https://doi.org/10.1016/S0377-2217(97)00244-0

15) Garg, A., \& Deshmukh, S.G. (2006). Maintenance management: literature review and directions. Journal of quality in maintenance engineering, 12(3), 205-238. DOI: https://doi.org/10.1108/13552510610685075

16) Guarda, A. \& Felipe, E., (2015). Documento Suape 2015: Retomada necessária. Especiais JC Online. Jornal do Commercio. Recife, 7 July, 2015. Available at: http:// especiais.jconline.ne10.uol.com.br/documento-suape-2015/(accessed 9 December 2015).

17) Hair, Jr. J., \& Page, M. (2018). The Essentials of Business Research Methods, 13rd Edition. McGraw Hill Education.

18) HajShirmohammadi, A., \& Wedley, W.C. (2004). Maintenance management-an AHP application for centralization/decentralization. Journal of Quality in Maintenance Engineering, 10(1), 1625. DOI: https://doi.org/10.1108/13552510410526839

19) Hansen, R. C. (2005). Overall Equipment Effectiveness: a powerful production/maintenance tool for increase profits, Industrial Press Inc., New York.

20) Huang, C. T., Yeh, T. M., Lin, W. T., \& Lee, B. T. (2009). A fuzzy AHP-based performance evaluation model for implementing SPC in the Taiwanese LCD industry. International Journal of Production Research, 47(18), 5163-5183. DOI: https://doi.org/10.1080/00207540801935608 
21) Jain, A., Gupta, R.C., \& Soni, S. C. (2014). Analytical Hierarchy Process for Identification of Attributes for TPM Implementation, Voice of Research. 3(3), 41-45.

22) Jain, A., Singh, H., \& Bhatti, R. S. (2018). Identification of key enablers for Total Productive Maintenance (TPM) implementation in Indian SMEs: a graph theoretic approach. Benchmarking: An International Journal, 25(8), 2611-2634. DOI: https://doi.org/10.1108/BIJ$\underline{\text { 02-2016-0019 }}$

23) Jha, C.K., \& Singh, A. (2016). Study of Total Productive Maintenance: A Case Study of OEE Improvement in Automobile Industry, Benefits and Barriers in TPM Implementation. International Journal for Technological Research in Engineering, 3(9), 2400-2406.

24) Jasiulewicz-Kaczmarek, M. \& Saniuk A., (2017). How to Make Maintenance Processes More Efficient Using Lean Tools? in Richard H.M. Goossens (ed.), Advances in Social \& Occupational Ergonomics, Proceedings of the AHFE 2017 International Conference on Social \& Occupational Ergonomics, Advances in Intelligent Systems and Computing, 605, 9-20.

25) Jerônimo, T. B., Melo, F. J. C., \& Aquino, J. T. (2016). An implementation of the multi-criteria decision model: how managers apprehend the importance of rational decisions. Exacta, São Paulo, 14(2), 319-334.DOI: https://doi.org/10.5585/ExactaEP.v14n2.6409

26) Kodali, R., \& Chandra, S. (2001) Analytical hierarchy process for justification of total productive maintenance. Production Planning \& Control: The Management of Operations, 12(7), 695-705. DOI: https://doi.org/10.1080/09537280010024045

27) Kodali, R., Prasad Mishra, R., \& Anand, G. (2009). Justification of world-class maintenance systems using analytic hierarchy constant sum method. Journal of Quality in Maintenance Engineering, 15(1), 47-77. DOI: https://doi.org/10.1108/13552510910943886

28) Küçük, B. B. \& Korkut, D. S. (2016). Investigation of total productive maintenance facilities in forest products industry, example of Inegöl. Kastamonu Üniversitesi Orman Fakültesi Dergisi, 16(2), 401-411. DOI: https://doi.org/10.17475/kastorman.289750

29) Labib, A.W., O'Connor, R.F., \& Williams, G.B. (1998). An effective maintenance system using the analytic hierarchy process. Integrated Manufacturing Systems, 9(2), 87 - 98. DOI: https://doi.org/10.1108/09576069810202005

30) Labib, A.W., Corte, M.C., \& Williams, G.B. (1997). Towards a world class maintenance programme. CIRP International Symposium on Advanced Design and Manufacture in the Global Manufacturing Era. Hong Kong, 1, pp. 82-88.

31) Madu, C. N. (1994). On the total productivity management of a maintenance float system through AHP applications. International journal of production economics, 34(2), 201-207. DOI: https://doi.org/10.1016/0925-5273(94)90036-1

32) Manihalla, P. P., Gopal, R. C., Rao, S. T., \& Javaraiah, R. M. (2019). A survey on factors affecting total productive maintenance (TPM) in service industries. In AIP Conference Proceedings. 2080(1), 060005. DOI: https://doi.org/10.1063/1.5092940

33) Moraes, J., \& Clemente, A. (2015). Toyota confirms parts warehouse in the Suape Port Complex. Diário de Pernambuco, Recife, 4 May 2015. Available at: http://www.diariodepernambuco.com.br/app/noticia/economia/2015/02/11/internas_econo 
mia,560380/toyota-confirma-galpao-de-pecas-no-complexo-portuario-de-suape.shtml (accessed 4 May 2015).

34) Nakajima, S. (1988). Introduction to TPM - Total Productive Maintenance, Cambridge, MA: Productivity Press.

35) Netland, T.H. \& Sanchez, E. (2014). Effects of a production improvement programme on global quality performance: The case of the Volvo Production System. The TQM journal, 26(2), 188201. DOI: https://doi.org/10.1108/TQM-03-2012-0023

36) Pačaiová, H., \& Ižaríková, G. (2019). Base Principles and Practices for Implementation of Total Productive Maintenance in Automotive Industry. Quality Innovation Prosperity, 23(1), 45-59. DOI: https://doi.org/10.12776/qip.v23i1.1203

37) Piechnicki, A. S., Sola, A. V. H., \& Trojan, F. (2015). Decision-making towards achieving world-class total productive maintenance. International Journal of Operations \& Production Management, 35(12), 1594-1621. DOI: https://doi.org/10.1108/IJOPM-11-2013-0479

38) Raouf, A. \& Ben-Daya, M. (1995). Total maintenance management: a systematic approach. Journal of Quality in Maintenance Engineering, 1(1), 6-14. DOI: https://doi.org/10.1108/13552519510083093

39) Saaty, T. L. (1977). A scaling method for priorities in hierarchical structures. Journal of Mathematical Psychology, 15(3), 234-281. DOI: https://doi.org/10.1016/0022-2496(77)90033$\underline{5}$

40) Saaty, T. L. (1986). Axiomatic Foundation of The Analytic Hierarchy Process. Management science, 32(7), 841-855.

41) Saaty, T. L. (1990). How to make a decision: the analytic hierarchy process. European journal of operational research, 48(1), 9-26. DOI: https://doi.org/10.1016/0377-2217(90)90057-I

42) Saaty, T. L. (2008). Decision making with the analytic hierarchy process. International Journal Services Sciences, 1(1), 83-98. DOI: https://doi.org/10.1504/IJSSci.2008.01759

43) Sadeghi, A., \& Manesh, R. A. (2012). The application of fuzzy group analytic network process to selection of best maintenance strategy-a case study in mobarakeh steel company, Iran. Procedia-Social and Behavioral Sciences, 62, 1378-1383. DOI: https://doi.org/10.1016/j.sbspro.2012.09.236

44) Sahoo, S. (2019). Assessment of TPM and TQM practices on business performance: a multi-sector analysis, Journal of Quality in Maintenance Engineering, 25(3), 412-434. DOI: https://doi.org/10.1108/JQME-06-2018-0048

45) Shafiee, M. (2015). Maintenance strategy selection problem: an MCDM overview. Journal of Quality in Maintenance Engineering, 21(4), 378-402. DOI: https://doi.org/10.1108/JQME-09$\underline{2013-0063}$

46) Sharma, A., Yadava, G. S., \& Deshmukh, S. G. (2011). A literature review and future perspectives on maintenance optimization. Journal of Quality in Maintenance Engineering, 17(1), 5-25. DOI: https://doi.org/10.1108/13552511111116222 
47) Sharma, M. \& Kodali, R. (2008). TQM implementation elements for manufacturing excellence. The TQM Journal, 20(6), 599-621. DOI: https://doi.org/10.1108/17542730810909365

48) Sharma, V., Gidwani, B. D., Sharma, V., \& Meena, M. L. (2019). Implementation model for cellular manufacturing system using AHP and ANP approach. Benchmarking: An International Journal, 26(5), 1605-1630. DOI: https://doi.org/10.1108/BIJ-08-2018-0253

49) Shinde, D. D. \& Prasad, R. (2018). Application of AHP for ranking of total productive maintenance pillars. Wireless Personal Communications, 100(2), 449-462. DOI:

https://doi.org/10.1007/s11277-017-5084-4

50) Singh, M., Sachdeva, A., \& Bhardwaj, A. (2012). Measuring manufacturing performance with the implementation of TPM: an exploratory study, International Journal Productivity and Quality Management, 9(4), 456-471. DOI: https://doi.org/10.1504/IJPQM.2012.047192

51) Singh, R. \& Kumar, H. (2017). Role of TPM Paradigms in Achieving Manufacturing Excellence in Industry, International Journal of Innovative Research in Science, Engineering and Technology. 6(8), 16624. DOI: https://doi.org/10.15680/IJIRSET.2016.0608116

52) Singh, U. \& Ahuja, I.S. (2015). Evaluating the contributions of total productive maintenance on manufacturing performance, International Journal of Process Management and Benchmarking, 5(4), 425-455. DOI: https://doi.org/10.1504/IJPMB.2015.072324

53) Sivaram, N.M., Devadasan, S.R., Murugesh, R., Karthi, S., \& Sreenivasa, C.G. (2014). Synergizing total productive maintenance elements with ISO 9001: 2008 standard based quality management system. The TQM Journal, 26(6), 534-549. DOI: https://doi.org/10.1108/TQM$\underline{08-2012-0059}$

54) Slack, N., Chambers, S., \& Johnston, R. (2007). Operations Management. 5. ed. Edinburgh Gate, Harlow, Essex CM20 2JE: Prentice Hall / Financial Times / Pearson Education.

55) Sousa, J. V. (2017). Examinando as Perdas em Indústrias de SUAPE Conforme a Ótica do Lean System - 1 ed. Appris, Curitiba, PR.

56) Sousa, J. V., Jerônimo, T. B., Melo, F. J. C. \& Aquino, J. T. (2017). Use of AHP to identify quality losses in manufacturing companies: a case study. Exacta, 15(1), 89-100. DOI: https://doi.org/10.5585/exactaep.v15n1.6691

57) Stefano, F. \& Kojikovski, G. (2015). Every minute 7 people lose their jobs in Brazil. Revista Exame.com. 10 October 2015. Available at: http://exame.abril.com.br/revistaexame/edicoes/1099/noticias/a-cada-minuto-7-pessoas-perdem-o-emprego-no-brasil (accessed 5 December 2015).

58) Stevenson, W. J. (2014). Operations Management. 20. ed. McGraw-Hill Series in Operations and Decision Sciences, New York: NY.

59) Suape (Industrial Port Complex). (2017). Suape Complex, Available at: http://www.suape.pe.gov.br/complexo_suape.asp. (accessed 15 February 2017).

60) Takahashi, Y. \& Osada, T. (1990). TPM: Total Productive Maintenance. Asian Productivity Organization, Tokyo. 
61) Upadhyaya, G. \& Bhat, S. (2016). The effect of contingencies on mutual influence among quality awards and quality initiatives. The TQM Journal, 28(6), 814-833. DOI: https://doi.org/10.1108/TQM-09-2014-0080

62) Van der Wal, R.W.E., \& Lynn, D. (2002). Total productive maintenance in a South African pulp and paper company: a case study. The TQM Magazine, 14(6), 359-366. DOI: https://doi.org/10.1108/09544780210447465

63) Wind, Y., \& Saaty, T. L. (1980). Marketing Applications of The Analytic Hierarchy Process. Management Science. 26(7), 641-658. DOI: https://doi.org/10.1287/mnsc.26.7.641 